\title{
An Analysis of Groundwater Irrigation Expansion in India
}

\author{
Anik Bhaduri ${ }^{1}$, Upali Amarasinghe ${ }^{2}$ and Tushaar $\mathrm{Shah}^{3}$
}

\begin{abstract}
Currently, groundwater irrigation is the most dominant form of irrigation in India. The paper explores whether the canal irrigation recharge has been a necessary condition for the recent groundwater expansion and also test the alternative hypothesis that groundwater boom in India is largely contributed by demand factors, for instance, rural population density. In the paper, we made an attempt to assess the contribution of different sources of irrigation to the growth of gross irrigated area, which reflects the irrigated land use intensity.

Regression models based on district level panel data were used in this study. The estimated results suggest that groundwater irrigation expansion is driven mainly by the population pressure, and not necessarily dependent on the change in surface water irrigation. However, the marginal effect of groundwater irrigation on gross irrigated area is largely determined by supply conditions like recharge from surface irrigation. In the districts irrigated by groundwater only, our findings indicate that the marginal effect on gross irrigated area is lower than that in the district endowed with both surface and groundwater irrigation facilities. In a situation where groundwater irrigation is the dominant form of irrigation, any surface water irrigation project in future would thus facilitate better groundwater utilization and helps in increasing the land use intensification.
\end{abstract}

Key words: Groundwater; Gross irrigated area; Irrigated land use intensification.

\section{INTRODUCTION}

Over the last century, the global population has tripled, and water consumption has increased threefold (UNESCO 2005). Water use in India is no exception to this general trend.

The main cause of the increase are growing population and rising food demand. In an agrarian economy like India, the importance of water for agricultural productivity hardly needs any emphasis. Currently, in India irrigation contributes 40 percent of the crop area and 70 percent of the total crop production. Improved reliability of water supply through canals or, more significantly through groundwater, has significantly contributed to the increase in agricultural productivity in India (Brown 2003). India faces the daunting task of increasing its food

\footnotetext{
${ }^{1}$ Anik Bhaduri is a Postdoctoral research Fellow at International Water Management Institute, New Delhi, India.

${ }^{2}$ Upali Amarasinghe is a Senior Researcher at International Water Management Institute, New Delhi, India.

${ }^{3}$ Tushaar Shah is a Principal Researcher at International Water Management Institute, Anand, India.
} 
production by over 50 percent in the next two decades, and reaching towards the goal of sustainable agriculture requires a crucial role of water (Kumar 1998). Recent studies show that the irrigation needs to play a larger role towards a goal of achieving a higher agricultural productivity and the national food security (Persaud et al. 2003; Kumar 1998, GOI 1999).

The National Commission of Integrated Water Resources Development (NCIWRD) projections show that irrigated area needs to increase by about 61 percent or 35 million ha in year 2025 to reach the food self sufficiency goals (GOI 1999). Currently, India is on a cross road to decide about the ways to meet the future water demand and is thinking at the discussion level to link the Himalayan Rivers with the Peninsular Rivers using several major link canals. Many opponents of the Government of India's National River linking project argue that groundwater irrigation can contribute in much of the additional irrigation needs in the future. It is true that groundwater has been the major driver of net irrigated area expansion in the last two decades (FAO 2002). But how long can this trend continue-in which location and in what magnitude? And how will the net groundwater area expansion contribute to gross irrigated area growth? To answer such questions it is necessary to review the past spatial and temporal trends of surface and groundwater irrigation and assess their contributions to the gross irrigated area growth.

The recent boom in ground water irrigation is due to many reasons. First, due to slow down in the growth of public investments in large-scale irrigation infrastructure and incompletion of on going projects, the surface irrigated area has not increased in the 1990's (Gulati et.al 1999). The most severe problem facing Indian canal irrigation, however, is the rapid deterioration of systems that have already been created (Gulati et.al 1999). In the absence of new large-scale surface irrigation schemes, and the availability of low cost electric and diesel pumps coupled with little or no electricity charges, the groundwater has been a major driver in the 
irrigated area expansion. Second, expansion of groundwater-irrigated areas is in large part due to increase in the reliability of water supply. Groundwater irrigation, due to its lesser variation in its supply and higher reliability in irrigated water supply, reduces the risk of investment in labour, seed, fertilizers, pesticides and other inputs and induces the farmers to increase the agricultural productivity.

It is popularly believed that the recent groundwater irrigation expansion was taking place in and close to irrigation command areas, where recharge from canal irrigation is the main source of groundwater availability. We hypothesize such widely held belief and examine whether canal irrigation recharge is a necessary condition for the groundwater expansion. We also test the hypothesis that groundwater boom in India is largely contributed by demand factors, for instance, rural population whose livelihood dependent mostly from agriculture.

There are two main sources of growth in gross irrigated area: expanding the irrigated area, and increasing the frequency with which it is irrigated (irrigated land use intensity i). India's net irrigated area has expanded by 24 and 18 percent in the 1980's and 1990's. The irrigated land use intensity, representing one of the criteria of irrigated land productivity, has increased by only 10 percent over the past two decades. The average national irrigation land use intensity in 2000 was 138 percent. Is there any scope for increasing irrigation intensity further in existing lands? How will the surface and groundwater irrigation contribute to the increase in irrigation intensity? Answers to these are important to know how much new surface irrigated to develop for meeting future needs. Therefore, with a view to evaluate investment in major and minor irrigation projects in the light of intensive land use cropping, we here made an attempt to assess the contribution of different sources of irrigation on gross irrigated area, which reflects the irrigated land use intensity. 
The structure of the paper is as follows. In the next section, we discuss the study objective, data and methodology. In the following section discusses the spatial and temporal trends associated with the groundwater boom in India. In the third section, we review the growth of irrigated area of India in the past, and assess the contribution of different sources of irrigation on gross irrigated area. Finally, the last section summarizes the findings and results of the paper.

\section{STUDY OBJECTIVES, DATA AND METHODOLOGY}

The major objectives of this study are to assess the spatial and temporal trends of surface and groundwater irrigated area development in India and their contribution to gross irrigated area growth. Specifically this study assess

1. Whether the growth in surface irrigation is a necessary factor in net groundwater irrigated area growth,

2. Whether the rural population is a driver in groundwater expansion and if so where it is most significant,

3. The relative contribution of surface and groundwater irrigation in increasing the gross irrigated area

\section{Data}

We use a combination of time series and cross sectional data for our analysis. The time series data from 1951 to 2001 assess the national level temporal trends of net surface, tanks and groundwater irrigated area growth; and the sources of this data are the various issues of “Agriculture at a Glance" publications by the ministry of agriculture (GOI 2004). The district level net surface, tank and groundwater irrigated areas in 2000 assess the spatial trends, and the sources for this data are various publications of Fertilizer Statistics (FIA 2000). The relative contributions to gross irrigated area growth are assessed using time series and cross section data of 16 major states in India. These 16 states constitute more than $95 \%$ of the agrarian economy of 
India, for the period 1990-1996. Instead of using aggregate time series data only, we use panel data, where the cross sectional units are the different district. . There are several advantages in doing empirical study using panel data. Panel data facilitate with a large number of data points, and thus increasing the degrees of freedom and reducing the collinearity among explanatory variables. Hence, it improves the efficiency of estimates. Agricultural productivity and irrigated water depends on many unobserved variables. Panel data reduce the endogeniety or the heteroscedasticity problem, inherent in the estimation, by utilizing the information on both the intertemporal dynamic and the individuality of the entries, which are the different states here. However, as we are estimating variance parameters for each panel (or possibly covariances between panels), the estimates require many time-periods per panel for consistency; and in our data set we have included ten years long time frame for each panel to gain consistency in estimation. This allows for district-specific variation in all the variables included, as compared to all- India data that could reduce such variation by aggregating some variables and averaging others. The source of this data is the database available in International Crops Research Institute for Semi Arid Tropics (ICRISAT).

\section{GROUND WATER IRRIGATION BOOM IN INDIA}

Groundwater irrigation has contributed in much of the increase in the net irrigated area of the country over the last few decades (Figure 1). The figure 1 highlight the groundwater irrigation expansion relative to that of the net irrigated area; and not major difference in the slopes of the two curves is reflected in the last few decades, which supports the claim that that most of the increase in net irrigated area is caused by groundwater irrigation. In the past, surface water irrigation had played a significant role in increasing the net irrigated area. However from mid sixties, the proportion of surface water to net irrigated area has decreased and in the last 
decade alone it has decreased largely by $23 \%$. Policy makers claim that this is largely due to incompletion of planned irrigation projects and poor maintenance of the existing surface irrigation infrastructure (Gulati et.al 1999).

There seem to be three distinct periods of groundwater irrigation growth. Between 1950 and 1966, the groundwater contribution increased from 28 percent to 34 percent of the net irrigated area. During this phase groundwater irrigation development was confined mainly to the arid and semi arid regions of the western India. In Gujarat, for instance, groundwater irrigation was the only predominant source of irrigation, and accounted for more that $80 \%$ of the net irrigated area. Since 1967, groundwater expanded rapidly and overtook the surface irrigated area by 1982 . Over the period from 1967 to 1982 , groundwater added 11 million ha to the net irrigated area at a compound growth rate of $4.2 \%$ compare to $2 \%$ in the previous phase; while the surface irrigated area expanded only by 3 million ha. This phase can be linked to the period of green revolution agriculture, which was water intensive in nature and dependent on timely and assured supply of water. The necessity of assured water supply posed in the 1960s by the advent of green revolution technology provided the early impetus for the ground water development in India. Evidence strongly reveals that during this period, groundwater expansion had taken place mainly in the agricultural states like Punjab, Haryana; and the correlation between groundwater irrigation expansion and surface irrigation development is strong in this phase. The last phase, between 1982 and 2001, shows continuation of accelerated groundwater expansion at a rate of $3.14 \%$ growth rate, and virtually no growth in surface irrigation. During this phase, groundwater irrigation growth also has taken momentum in the eastern and southern India, and mainly driven by demand factors like population pressure. By 2000, the groundwater irrigated area of 35 million ha accounted for 61 percent of the total net irrigated area in India. ${ }^{\text {ii }}$ 
To get further insight, we explore the state wise net irrigated area (NIA) and the groundwater irrigation share in Table 1. The table shows the NIA and groundwater irrigated area as a percentage of NIA for the periods 1961-63, 1971-73 , 1981-83 , 1991-93 and 1998-2000. Many climatic factors like rainfall and drought affect irrigation. So, we have taken a three-year average for the periods mentioned.

National growth of groundwater irrigation masks the regional variation in groundwater irrigation expansion. There is state wise variation in the groundwater source of net irrigated area, which is reflected in Table 1. Part of this disparity in groundwater irrigation development can be explained by the fact that during the period of the Green Revolution, Punjab and Haryana were way ahead of other states in terms of irrigated area; and in the western states, particularly Gujarat and Rajasthan, groundwater was the major available source for irrigation in the post independence period. In the period post -1997, the proportional of groundwater irrigation to net irrigated area became more than $60 \%$ in the northern and western states, while the share of groundwater irrigation is still less than $50 \%$ in the southern zone. Here the hydro-geomorphological features are not as favorable as in the alluvial plains of Gangetic basin, for recharge.

In the latter geographic zone, growth is mainly confined in Andhra Pradesh and Kerala, whereas not much growth has taken place in the Tamil Nadu and Karnataka due to declining groundwater table. The rate of expansion on ground water irrigated area in the eastern India (West Bengal and Bihar) is phenomenally high compared to the other states during 1990's. Recent studies also show that more than one-third of total pumps number in India in early 1990 was in the state of West Bengal alone (Bhattarai et.al 2003). 


\section{Surface Irrigation Recharge and Groundwater Area Growth: Spatial dependence}

A popular belief is that surface water recharge is a necessary condition for the expansion of groundwater-irrigated area. Groundwater pumping costs generally depend on the water table level, which means that as the groundwater stock is increased, marginal extraction costs falls. Higher surface water withdrawals recharge the aquifers and induce the farmers to increase groundwater usage and expand the gross irrigated area.

It could be true that surface irrigation recharges groundwater not only in the canal command areas, but also in the rainfed areas outside the canal commands. But, how widespread can this recharge be, and to what extent this contributes to NGWIA expansion?

We attempt to address the issue by investigating the link between surface irrigation recharge and the groundwater irrigation expansion using spatial auto correlation analysis. Here, first we attribute the groundwater area expansion within a district to the surface irrigation in that district. How would then the surface irrigation within a district associated with the groundwater irrigation in the surrounding districts? Our null hypothesis is that the groundwater expansion in the surrounding districts is dependent on the surface irrigation of the central district. Spatial autocorrelation show the spatial dependence of a unit with its neighbours.

\section{Methodology}

We use piece wise time series regression analysis to assess the temporal variation of net surface and groundwater irrigated area growth. Spatial autocorrelation analyzes the spatial association of groundwater and surface irrigation expansion. The global Moran's I, a measure of spatial autocorrelation, show the strength of the spatial dependence of a unit with its neighbouring units (Anselin 1995). Moran's I is the degree of linear association of a variable in X-axis with its 
spatial lag variable in the $\mathrm{Y}$-axis. Let $\mathrm{x}_{1} \mathrm{x}_{2}, \ldots . \mathrm{x}_{\mathrm{n}}$ be observations of $\mathrm{N}$ locations of surface irrigated area and $\mathrm{y}_{1}, \mathrm{y}_{2}, \ldots . \mathrm{y}_{\mathrm{n}}$ be observations of groundwater irrigated area.

Global Morans's I is defined as

$I=\frac{N}{w_{0}} \frac{\sum_{i=1}^{N} \sum_{j=1}^{N} w(i, j)\left(x_{i}-\bar{x}\right)\left(y_{j}-\bar{y}\right)}{\sum_{i}^{N}\left(x_{i}-\bar{x}\right)^{2}}$, where $\mathrm{w}(\mathrm{i}, \mathrm{j})$ define the spatial weight explaining the proximity of different locations and $w_{0}=\sum_{i=1}^{N} \sum_{j=1}^{N} w(i, j)$.

The Morans's I takes values between -1 and 1. The two extremes indicate high-high or low-low spatial dependence (Morans I =1) and high-low and low-high spatial dependence (Moran's I=-1). Moran's I close to zero show no significant pattern of spatial dependence.

For our analysis, we estimate the bivariate Moran's I. The bivariate Moran's scatter plot shows the spatial lag of the groundwater-irrigated area variable in the Y-axis and the surface irrigated area variable in the X-axis. The Moran's I not significantly different from zero support our hypothesis that groundwater expansion of a units is not necessarily associated with the surface irrigation expansion of the neighboring units.

Figure 2 is the scatter plot of the surface irrigated area in the $\mathrm{X}$ - axis and the spatial lag of the groundwater irrigated area in the $\mathrm{Y}$-axis. The spatial autocorrelation, which indicates the strength of the linear relationship of the two variables, is not significantly different from zero. This contradicts the hypothesis that the surface irrigation is a necessary condition for large-scale expansion of groundwater expansion in surrounding areas. 


\section{Groundwater area expansion: Demand driven factors}

As groundwater is tapped in cases where the resource is not necessarily recharged by surface irrigation, the alternative hypothesis could be that demand driven factors are behind the groundwater expansion. Evidence suggests that groundwater expansion is taking place where people are, and is not necessarily dictated by the endowment of groundwater resource.

The most important challenge that most reviews of India's future agriculture is that of exploding population (Patel 2004; Thakkar 1999). India's current population is 1100 million and is projected to increase to about 1600 million by 2050. For major part of this population agriculture will remain as the primary source of livelihood (Kundu et.al 2006). India's agriculture dependent population relative to the total population has been decreasing over the last few decades. However, the total agriculture population is increasing, albeit at a decreasing rate of 1.1 percent in the 1980 's and 1.0 percent in the 1990's. Despite the increasing agriculture dependent population, the net sown area (NSA) has remained more or less constant in the last decade $^{\text {iii }}$. Thus the population pressure and the need for adequate livelihood opportunities for the increasing population on the available agriculture land have increased substantially over this period.

Boserupian hypothesis states that increase in population density increases the intensification of agricultural factor use (Boserup 1981; Boserup 1965). We investigate whether the increase in rural population density will influence the groundwater-irrigated area of the country in the future and supports the Boserupian hypothesis.

We have used feasible generalized least square regression model for estimation with corrected state specific heteroscedasticity. The regression model shown below (equation 1) indicates positive association between groundwater irrigation expansion and rural population 
density. The results suggest that a percent increase in rural population density (RP) increases the proportion of groundwater-irrigated area $(\mathrm{GW})$ by $5 \%$. The R-square of 40 percent supports the claim that rural population density alone significantly accounts for the increase in groundwater irrigation expansion and supports the Boserupian hypothesis.

$G W=.03+.05 R P^{*}$

$(2.70)(6.99)$

$R^{2}=.39 \mathrm{n}=412$

* statistically significant at 0.001 level . Figures in parenthesis indicate the $t$ statistics.

Note: $\mathrm{GW}=$ groundwater irrigated area as a proportion to net sown area.

$\mathrm{RP}=$ rural-population density.

The results suggest a straightforward implication that in future with more growing population of India, there will be more pressure to expand the groundwater-irrigated area. Higher population will exogenously increase the demand for agricultural products and in the factor market there would be increased demand of irrigation to meet the agricultural demand of the population. Ground water irrigation being a democratic resource and easy -to -access source of irrigation always has the opportunity to respond to such increase in demand in a much shorter time path, which is not the case for surface irrigation schemes. Thus, groundwater remains the most popular choice among the farmers to meet the market demand. If similar trend continues, groundwater irrigation may continue to be the main source of irrigation to meet the future agricultural demand in India.

\section{GROWTH OF GROSS IRRIGATED AREA IN INDIA}

During the last fifty years, gross irrigated area (GIA) of India has increased more than three fold from 24 to 81 million Hectares. Gross irrigated area is a straightforward multiplicative function 
of net irrigated area (NIA) and irrigated land use intensity (IRLUI). Thus the relevant question, which may arise here, is the contribution of different sources of irrigation in increasing the gross irrigated area. ${ }^{\text {iv }}$ Figure 3 shows the change in net and gross irrigated area. The increasing vertical distance between the two curves signifies the contribution from the irrigated land use intensity. The figure below illustrates the increasing role of irrigation intensity, which has increased by more than $4 \%$ in the last decade.

There are state wise variations in irrigation, as reflected in Table 2. The level of irrigation is measured in terms of irrigated land use intensification (IRLUI) and irrigation ratio, (NIA/NSA) in percent. Table 2 shows the average of NIA, IRLUI, IR, and their corresponding growth rate. Table 2 shows high proportion of irrigated land, more than $70 \%$ in agricultural states like Punjab, Haryana and Uttar Pradesh where agriculture constitutes more than $30 \%$ of the state GDP. Among the southern states, proportion of irrigated land is below $30 \%$ in Karnataka and Kerala; while in Andhra Pradesh and Tamil Nadu, NIA/NSA is above 40\%.

Among the western states, Maharashtra has the lowest proportion of irrigated land where only $17 \%$ of the net cropped area is irrigated. Most of the eastern states are well endowed with irrigation where average NIA/NSA is 0.40. In the north-eastern state of Assam, however, less than $10 \%$ of net cropped area is irrigated. In Punjab and Kerala, there is a slight decrease in the proportion of irrigated area, even with an increase in NIA. It suggests that in post 1997 period, more rainfed area has been brought under cultivation in both the states. In the northern zone, there is hardly any room for irrigation development as $75 \%$ of the net cropped is irrigated, and is reflected in lower growth. The growth of irrigation area is striking in the western zone where NIA has grown by 46\% from 1990-1993 to 1997-2000. Eastern states register a much slower growth of irrigation except West Bengal. Among the southern states, higher growth in NIA took 
place in Andhra Pradesh and Tamil Nadu. All states register an increase in irrigated land use intensity (IRLUI). Much of this increase is noticed in states like Haryana, Himachal Pradesh, Karnataka, Kerala and Maharashtra. In Haryana, the increase in intensive use of irrigated land is contributed by limitation to increase the net irrigated area. In the latter three states, higher intensive use of land is also contributed by the choice of cropping pattern. In these four states, the share of permanent crops is high compare to other states.

In these states, however, the proportional irrigated area is not high. One possible reason could be that the opportunity cost of increasing the net irrigated area is higher than increasing the intensity. As a result, irrigated land use intensity became the major driver of gross irrigated area in these states with the development of minor irrigation.

\section{Gross Irrigated Area Expansion: Sources of Growth}

Different sources of irrigation contribute in increasing the gross irrigated area (GIA). These sources include canal irrigation, tank irrigation, and groundwater irrigation which includes both tube wells and dug wells. We assess the patterns of GIA growth in four groups. The first group consists of districts with canal, groundwater and tank irrigation. In these districts surface irrigation has indeed contributed to increasing groundwater recharge. The second group consists of districts with only canal-irrigated area. The third group consists of only groundwater irrigation districts. Before the introduction of groundwater, these districts were mainly rainfed districts. The groundwater recharge in these districts is mainly from rainfall. The fourth group of districts consists of only tank and groundwater irrigated area. These districts are located mainly in the southern peninsular states.

We use a simple ordinary least squares regression to assess the contribution of surface, tanks and groundwater area expansions to GIA. The regression in the first group of district, where canal, 
tanks as well as groundwater irrigation are present, a percent increase in groundwater irrigation will increase the GIA by 1.47 times. In the first group, a percent increase in canal irrigation will increase the GIA by 1.42 time. In districts without canal irrigation, the marginal contribution on GIA drops to 1.37. However, the marginal effect of groundwater contribution on gross irrigated area is only 1.22 in districts irrigated using groundwater only. The areas were primarily the rainfed areas where groundwater expansion has taken place. The marginal contribution of canal irrigation in the command area, where only canal-irrigated area is present, is 1.98. It implies that a percent increase in canal-irrigated area in command area will increase the gross irrigated area by $1.98 \%$. The regression results lead to following two key issues

Why the marginal effect of groundwater irrigation on gross irrigated area is not high in the districts without canal irrigation (third group)?

If there is not much significant difference with rainfed intensity why then the farmers irrigate with groundwater in such cases?

In the areas without canal irrigation, groundwater irrigation has expanded over the rainfed area and is based on natural recharge, which is affected by the vagaries of rainfall. Moreover, as ground water irrigation is the only form of irrigation, farmers overexploit the groundwater resource. Low groundwater recharge coupled with higher rate of withdrawal could be the reason for low irrigated land use intensity in the district where groundwater is the only form of irrigation. Despite limited scope of increasing the gross irrigated area, farmers still exploit groundwater in such areas to supplement the current water availability for higher yield. Higher agricultural productivity and population pressure are the factors behind groundwater expansion in such cases. 
Based on the current level gross irrigated area, and the regression trend given in Table 3 and equation 1, we analyse the sources of changes in gross irrigated, which has increased by $4.7 \%$ during the last decade. The computation of the source of gross irrigated area growth is based on the regression analysis (see Annex B for details). Table 4 shows the contribution of different sources to the relative change in average irrigation intensity.

Groundwater irrigation contributes around $90 \%$ of the relative change in gross irrigated area in India during the period 1990-1993 and 1998-2000, while canal irrigation contributes less than $10 \%$ of the change. Higher relative contribution of groundwater is also witnessed in all geographical zones. However, only in the east zone, relative contribution of canal irrigation is around $30 \%$, which is higher than that of other regions.

Both canal and tank irrigation is subject to external factors of varying rainfall, and coupled with decline in the performance of canal and tank irrigation has contributed in the decline of gross irrigated area in the last decade. These factors have compelled many farmers to shift to well irrigation, while groundwater irrigation has taken over much of the rainfed areas.

\section{CONCLUSION AND POLICY IMPLICATIONS}

Two important findings have come out of the paper. First, groundwater irrigation expansion is driven mainly by the demand conditions-the population pressure, and not necessarily dependent on the recharge from surface irrigation. Second, the gross irrigated area, which reflects the irrigated land use intensification, is largely explained by the supply conditions, for instance groundwater recharge; and it is evident as in the districts without canal irrigation, the marginal effect of groundwater irrigation on gross irrigated is lower than that in the district with both canal and groundwater irrigation facilities. 
It becomes apparent from the analysis that much of the groundwater irrigation expansion is taking place where there are no facilities of canal irrigation. With the availability of low cost electric and diesel pumps coupled with little or no electricity charges, the groundwater has been a major driver in the irrigated area expansion over the rainfed areas. However, groundwater recharge in these areas is heavily dependent on natural recharge from rainfall, which is again subject to uncertainty. Under such conditions over exploitation of groundwater may lead to well failures, which is already evident in southern and western India. In western India, half of the wells once in use are now out of commission (Debroy et. al 2003). This figure will increase as water tables decline. This is also the possible reason for the low land use intensity in areas irrigated only with groundwater.

Our results also suggest that groundwater irrigation when practiced in areas endowed with canal irrigation facilities, the irrigated land use intensity is high. One of the important uses of surface water irrigation is recharge of groundwater. Given sustainable stock of groundwater aided by recharge from canal irrigation, groundwater irrigation is the most reliable driver to increase the intensive use of irrigated land, one of the criteria of agricultural productivity. In a situation where groundwater irrigation is the dominant form of irrigation, any surface water irrigation project in future would thus facilitate better groundwater utilization and helps in increasing the land use intensification. 


\section{References}

Anselin, L. (1995) Local indicators of spatial association-LISA, Geographical Analysis 27: 93-115.

Bhattarai, Madhusudan ; A Narayanamoorthy. (2003) Irrigation and other Factors Contribution to the Agricultural Growth and Development in India: A Cross-State Panel Data Analysis for 1970 to 94, paper presented at the IWMI-Tata workshop in Anand, Gujarat, 27-29 January 2003

Boserup E. (1981) Population and technological chance: A study of long-term trends (Chicago,University of Chicago Press).

Boserup, E. (1965 )The Conditions of Agricultural Growth( London, Allen and Unwin).

Brown Lester R. (2003). Outgrowing the Earth: The Food Security Challenge( New York: W.W.Norton \& Company, 2005), pp. 86-87.

Damodaran A. (2000) Towards an Agro-Ecosystem Policy for India - Lessons from Two Case Studies (Ahmedabad, Tata-McGraw Hill, Environment and Development Series).

Deb Roy Aditi ; Tushaar Shah. (2002) The Socio-Ecology of Groundwater in India. Water Policy Briefing, Issue 4 IWMI-TATA .

FAI (2000). Fertilizer Statistics: 1999-2000 (New Delhi, Fertilizer Association of India )

FAO (2002)Crops and Drops. (FAO document 2002)

GOI .(2004) Agricultural Statistics at a Glance ( New Delhi, Ministry of Agriculture , Government of India)

GOI. (1999). Integrated Water Resource Development - A Plan for Action. Report of the National Commission for Integrated. Water Resources Development, Vol. - I. Ministry of Water Resources of India, Government of India, New Delhi.

Gulati, A; Ruth Meinzen-Dick; Raju , K. V. (1999). From Top Down to Bottoms Up: Institutional Reforms in Indian Canal Irrigation. (Delhi. Institute of Economic growth working paper)

Kanwar Sunil .(2004). Relative Profitability, Supply Shifters and Dynamic Output Response. The Indian Foodgrains (New Delhi ,Centre for Development Economics, Department of Economics, Delhi School of Economics, working paper no 133) 
Kumar, P .(1998).Food Demand and supply Projections for India (New Delhi, Agricultural Economics Policy Paper 98-01 .IARI )

Patel V. B (2004). Role of Irrigation and People's Participation in Meeting Food requirement. Journal of Applied Hydrology. Vol. XVII.

Persaud Suresh ; Stacey Rosen.( 2003) India's Consumer and Producer Price Policies: Implications for Food Security. Economics Research Service, Food Security Assessment ,GFA-14,Feb .

Roy B. C , S . Selvarajan ;B. Natesh .(2004) Methodological Issues in Future Water Food Security Analysis. Resource Analysis for Sustaining Water-Food Security (New DelhiNational Centre for Agricultural Economics and Policy Research, page 191-205).

Shah Tushaar ;Aditi Deb Roy; Asad S. Qureshi; Jinxia Wang (2003) Sustaining Asia's Groundwater Boom: An Overview of Issues and Evidence. Natural Resources Forum, 27 (2003) 130-140.

Thakkar, Himanshu .(1999) Assessment of Irrigation in India (A WCD Contributing Paper prepared as an input to the World Commission on Dams, Prepared for Thematic Review IV.2) 


\section{FIGURE 1.}

Groundwater and surface irrigated area during the last fifty years.

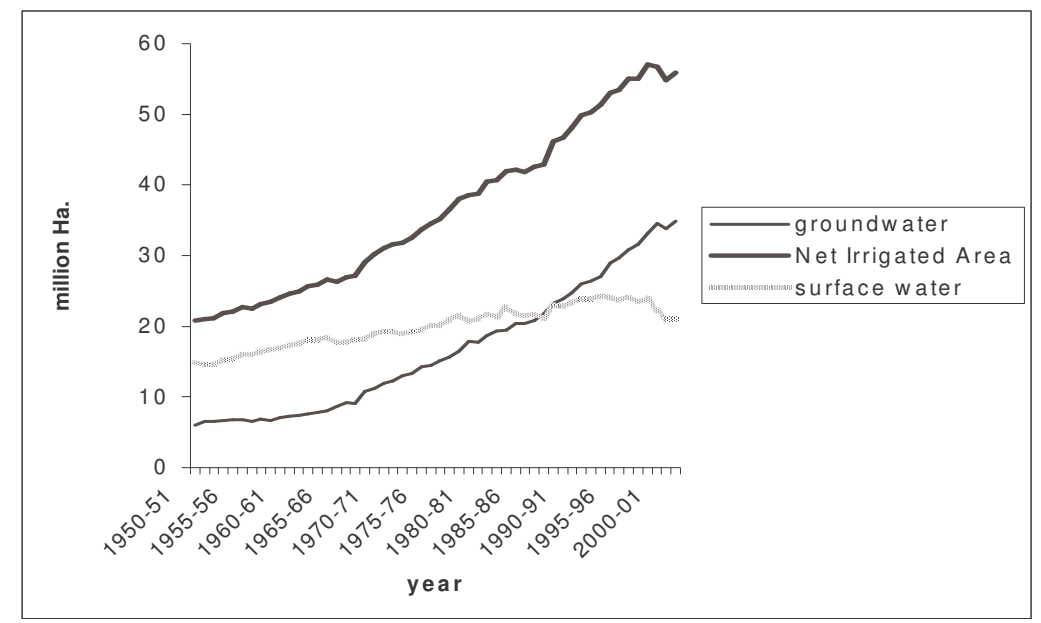

Source: Ministry of agriculture, Government of India.

Note: surface water includes both canal and tank irrigated area

\section{FIGURE.2}

Surface clusters of major groundwater irrigation districts.

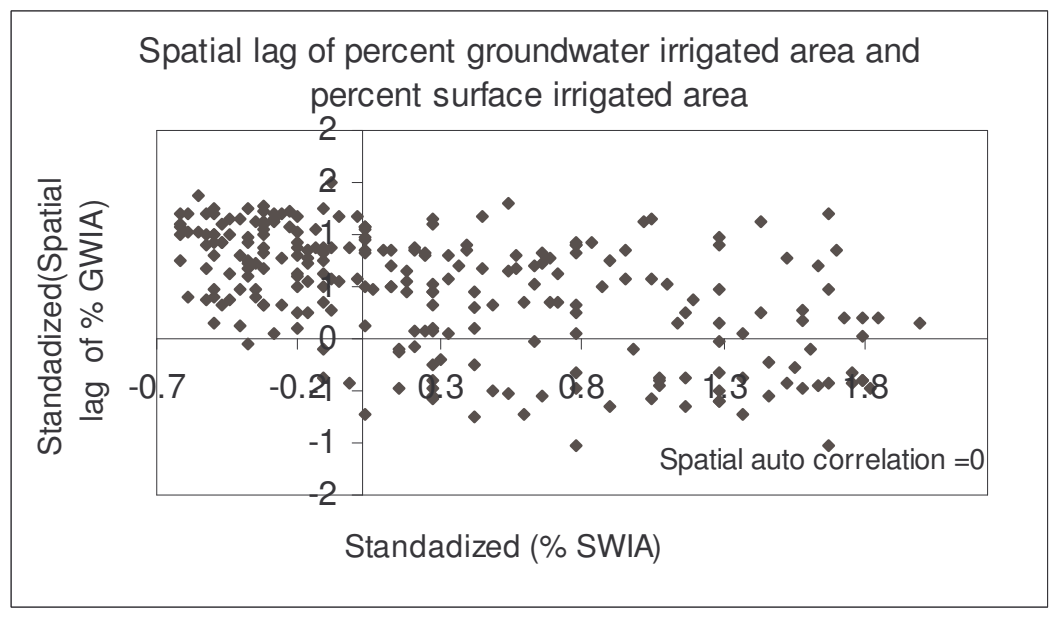


FIGURE 3.

Gross and Net irrigated area of India during 1950-2000.

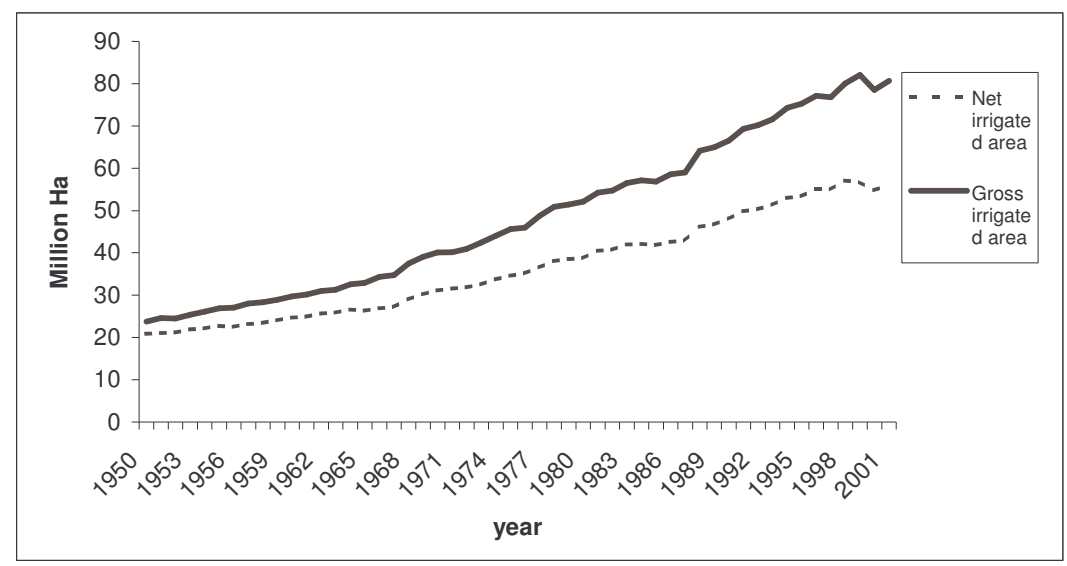

Source: Ministry of agriculture, Government of India.

TABLE 1.

State wise groundwater source of irrigation from the period 1961-1963 to1998-2000.

\begin{tabular}{|lcccccccccc|c|}
\hline & \multicolumn{9}{c}{ NIA } & '000 Hectares & \multicolumn{7}{c|}{ Ground water irrigated area - \% of NIA } \\
States & $1961-63$ & $1971-73$ & $1981-83$ & $1991-93$ & $1998-00$ & $1961-63$ & $1971-73$ & $1981-831991-931998-00$ \\
\hline Haryana & 1372 & 1576 & 2246 & 2631 & 2870 & -- & 39 & 46 & 47 & 50 \\
Himachal Pradesh & 40 & 92 & 92 & 99 & 110 & -- & 2 & 4 & 5 & 10 \\
Punjab & 3191 & 2961 & 3447 & 3904 & 4000 & 31 & 54 & 59 & 60 & 70 \\
Uttar Pradesh & 5060 & 7120 & 9626 & 10802 & 12570 & 47 & 57 & 61 & 70 & 73 \\
North & 9663 & 11750 & 15411 & 17436 & 19540 & & 53 & 58 & 62 & 68 \\
Assam & 617 & 572 & 572 & 572 & 570 & -- & -- & -- & - & 1 \\
Bihar & 1997 & 2274 & 2758 & 3348 & 3560 & 15 & 26 & 34 & 47 & 56 \\
Orissa & 1019 & 1072 & 1215 & 1979 & 2010 & 3 & 7 & 17 & 39 & 40 \\
West Bengal & 1351 & 1489 & 1604 & 1911 & 2130 & -- & -- & 14 & 37 & 52 \\
East & 4984 & 5407 & 6149 & 7811 & 8270 & 7 & 13 & 22 & 39 & 49 \\
Andhra Pradesh & 3040 & 3089 & 3560 & 4229 & 4350 & 13 & 18 & 22 & 32 & 43 \\
Karnataka & 907 & 1221 & 1439 & 2205 & 2510 & 16 & 26 & 27 & 34 & 39 \\
Kerela & 349 & 439 & 244 & 334 & 370 & 3 & 1 & -- & 20 & 30 \\
Tamil Nadu & 2478 & 2706 & 2513 & 2559 & 2960 & 24 & 31 & 41 & 45 & 50 \\
South & 6774 & 7454 & 7756 & 9327 & 10190 & 17 & 23 & 29 & 36 & 45 \\
Gujarat & 705 & 1290 & 2104 & 2502 & 2980 & 82 & 80 & 79 & 79 & 81 \\
Maharashta & 1093 & 1310 & 1927 & 2214 & 2950 & 56 & 58 & 57 & 55 & 65 \\
Madhya Pradesh & 963 & 1607 & 2470 & 4572 & 6180 & 34 & 38 & 42 & 49 & 69 \\
Rajasthan & 1807 & 2191 & 3101 & 4255 & 5360 & 56 & 54 & 63 & 61 & 70 \\
West & 4568 & 6399 & 9602 & 13543 & 17470 & 56 & 56 & 60 & 59 & 71 \\
India & 25479 & 31975 & 41048 & 50500 & 55910 & 30 & 40 & 47 & 52 & 61 \\
\hline
\end{tabular}

Source: Ministry of agriculture, Government of India.

Note: --denotes data not available. 
TABLE 2.

Irrigation scenario during the period 1990-1993 and 1998-2000.

\begin{tabular}{|c|c|c|c|c|c|c|}
\hline & \multicolumn{2}{|c|}{$1990-1993$} & \multicolumn{2}{|c|}{$1998-2000$} & \multicolumn{2}{|c|}{$\begin{array}{c}\text { Growth Rates } \\
\text { (Per Cent } \\
1997-2000 \\
\text { over 1990- } \\
1993) \%\end{array}$} \\
\hline States & $\begin{array}{l}\text { Irrigation } \\
\text { land use } \\
\text { intensity } \\
\text { (IRLUI) \% }\end{array}$ & $\begin{array}{c}\text { Irrigation } \\
\text { ratio (IR) } \\
\%\end{array}$ & $\begin{array}{l}\text { Irrigation } \\
\text { Land use } \\
\text { Intensity } \\
\text { (IRLUI) \% }\end{array}$ & $\begin{array}{c}\text { Irrigation } \\
\text { ratio (IR) } \\
\%\end{array}$ & IRLUI & IR \\
\hline Haryana & 132 & 74 & 140 & 80 & 6.1 & 8.1 \\
\hline Punjab & 138 & 95 & 139 & 94 & 0.7 & -1.1 \\
\hline Himachal Pradesh & 133 & 17 & 140 & 20 & 5.3 & 17.7 \\
\hline Uttar Pradesh & 140 & 61 & 141 & 71 & 0.7 & 16.4 \\
\hline North Zone & 136 & 67 & 139 & 75 & 2.2 & 11.9 \\
\hline West Bengal & 138 & 35 & 141 & 39 & 2.2 & 11.4 \\
\hline Bihar- & 123 & 46 & 124 & 48 & 0.8 & 4.4 \\
\hline Orissa & 130 & 32 & 131 & 33 & 0.8 & 3.1 \\
\hline Assam & 121 & 21 & 124 & 21 & 2.5 & 0 \\
\hline East Zone & 134 & 36 & 137 & 38 & 2.2 & 5.6 \\
\hline Karnataka & 134 & 20 & 140 & 24 & 4.5 & 20 \\
\hline Kerala & 133 & 17 & 139 & 17 & 4.5 & 0 \\
\hline Tamil Nadu & 136 & 43 & 137 & 54 & 0.7 & 25.6 \\
\hline Andhra Pradesh & 138 & 39 & 140 & 41 & 1.5 & 5.1 \\
\hline South Zone & 135 & 31 & 138 & 36 & 2.2 & 16.1 \\
\hline Gujarat & 124 & 23 & 129 & 31 & 4 & 34.8 \\
\hline Maharashtra & 135 & 11 & 140 & 17 & 3.7 & 54.6 \\
\hline MP & 131 & 20 & 132 & 31 & 0.8 & 55 \\
\hline Rajasthan & 136 & 24 & 137 & 33 & 0.7 & 37.5 \\
\hline West Zone & 133 & 19 & 136 & 28 & 2.3 & 47.4 \\
\hline INDIA & 132 & 35 & 135 & 39 & 2.3 & 11.4 \\
\hline
\end{tabular}

Note: IRLUI=irrigated land use intensity.

$\mathrm{IR}=$ Irrigation ratio defined as the net irrigated area to net sown area in percent. 
TABLE 3.

Regression results explaining the impact on gross irrigated area.

\begin{tabular}{|c|c|c|}
\hline Types of irrigation & & quation \\
\hline $\begin{array}{l}\text { Canals, tanks, and well } \\
\text { irrigated lands }\end{array}$ & 1 & 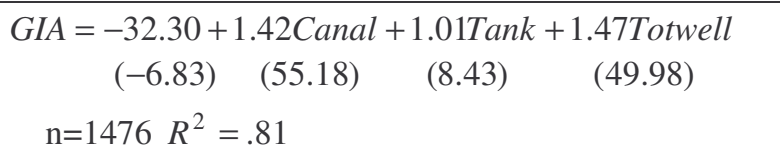 \\
\hline $\begin{array}{l}\text { Only canal irrigated } \\
\text { lands }\end{array}$ & 2 & $\begin{aligned} G I A= & 8.53+1.98 \text { Canal } \\
& (4.05) \quad(3.52) \mathrm{n}=312 \quad R^{2}=.30\end{aligned}$ \\
\hline Only well irrigated lands & 3 & $\begin{array}{l}\text { GIA }=16.92+1.22 \text { Totwell } \\
\qquad \begin{array}{ll}(3.56) \quad(20.68) \mathrm{n}=932 R^{2}=.62\end{array}\end{array}$ \\
\hline $\begin{array}{l}\text { Well and tank irrigated } \\
\text { lands }\end{array}$ & 4 & $\begin{aligned} \text { GIA }= & 6.88+1.29 \text { Tank }+1.36 \text { Totwell } \\
& (3.15) \quad(36.61) \quad(49.78) \mathrm{n}=1164 R^{2}=.76\end{aligned}$ \\
\hline
\end{tabular}

Note: Figures in parenthesis indicate the t statistics.

$\mathrm{GIA}=$ gross irrigated area.

Canal $=$ canal net irrigated area .

Tank=Tank net irrigated area.

Totwell=Total well (tube and dug well) net irrigated area.

TABLE 4.

Sources of gross irrigated area growth in the last decade.

Sources of GIA growth (\%)

INDIA North Zone East Zone South Zone West Zone

\begin{tabular}{lrrrrr} 
Canal & 9.55 & 13.99 & 30.24 & 5.96 & 19.05 \\
Tank & 1.89 & 0.53 & 1.26 & 5.96 & 2.25 \\
Groundwater & 88.56 & 85.48 & 68.49 & 88.08 & 78.70 \\
Total & 100.00 & 100.00 & 100.00 & 100.00 & 100.00 \\
\hline
\end{tabular}




\section{Annex A}

Maps showing the districts in India irrigated with groundwater and surface water in the year 2000.

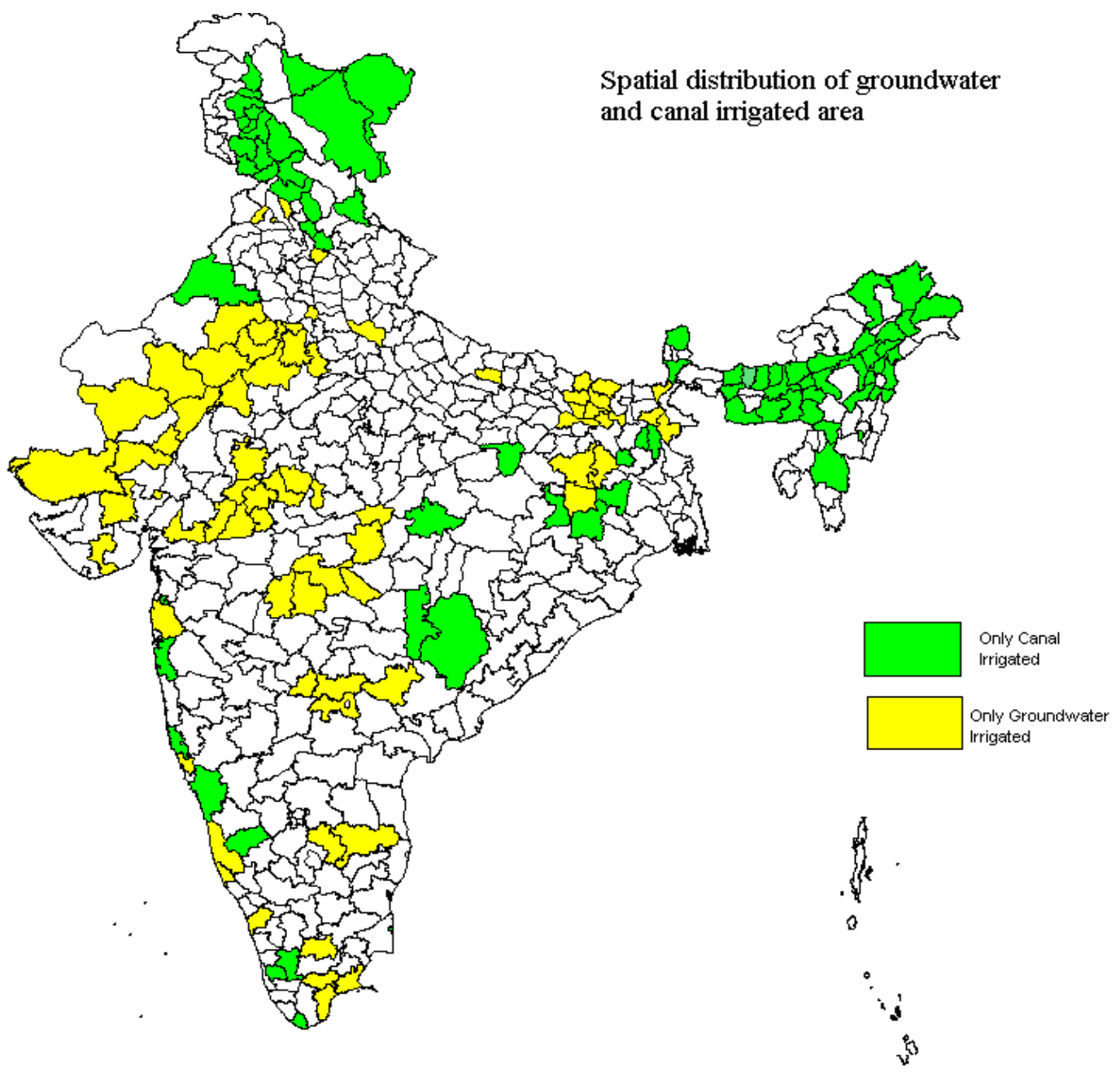




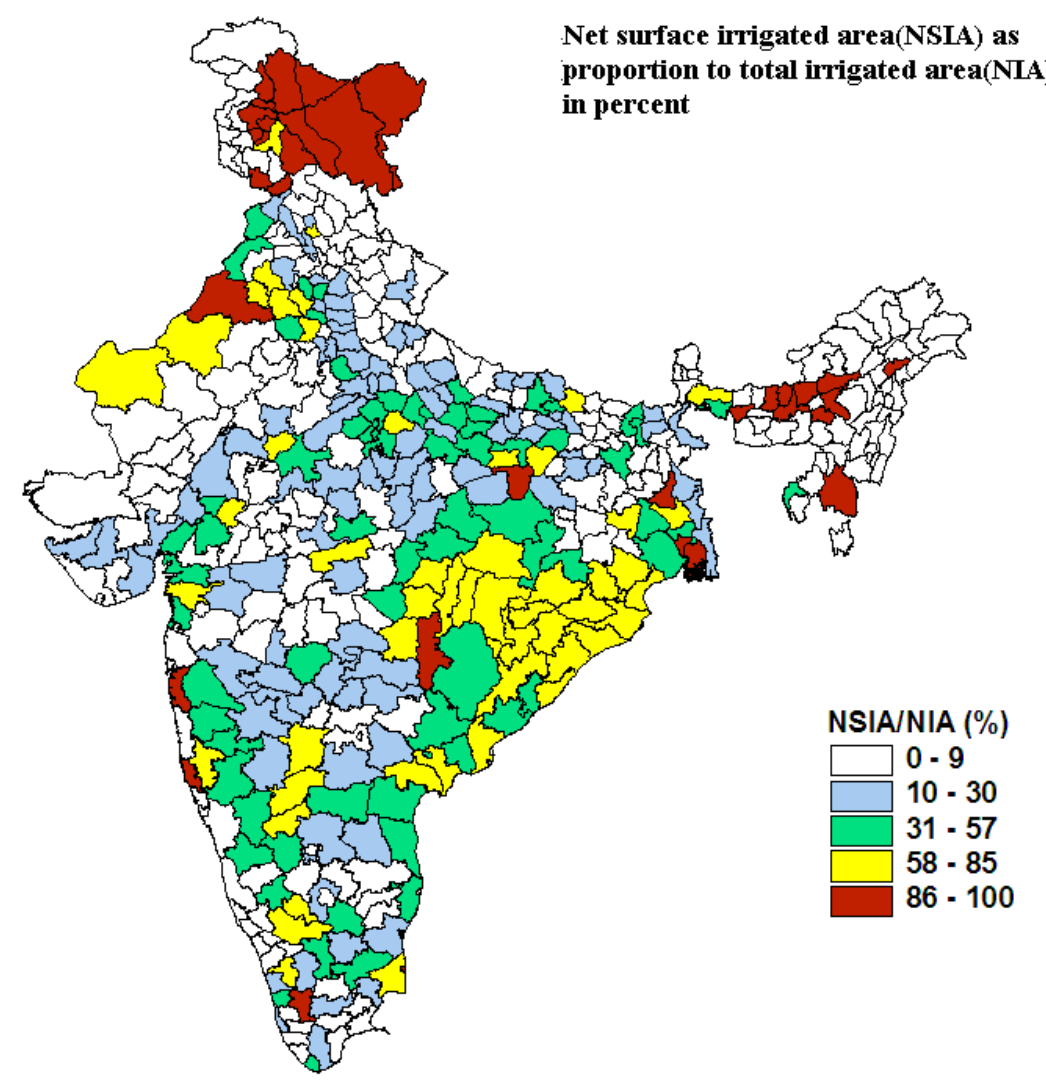




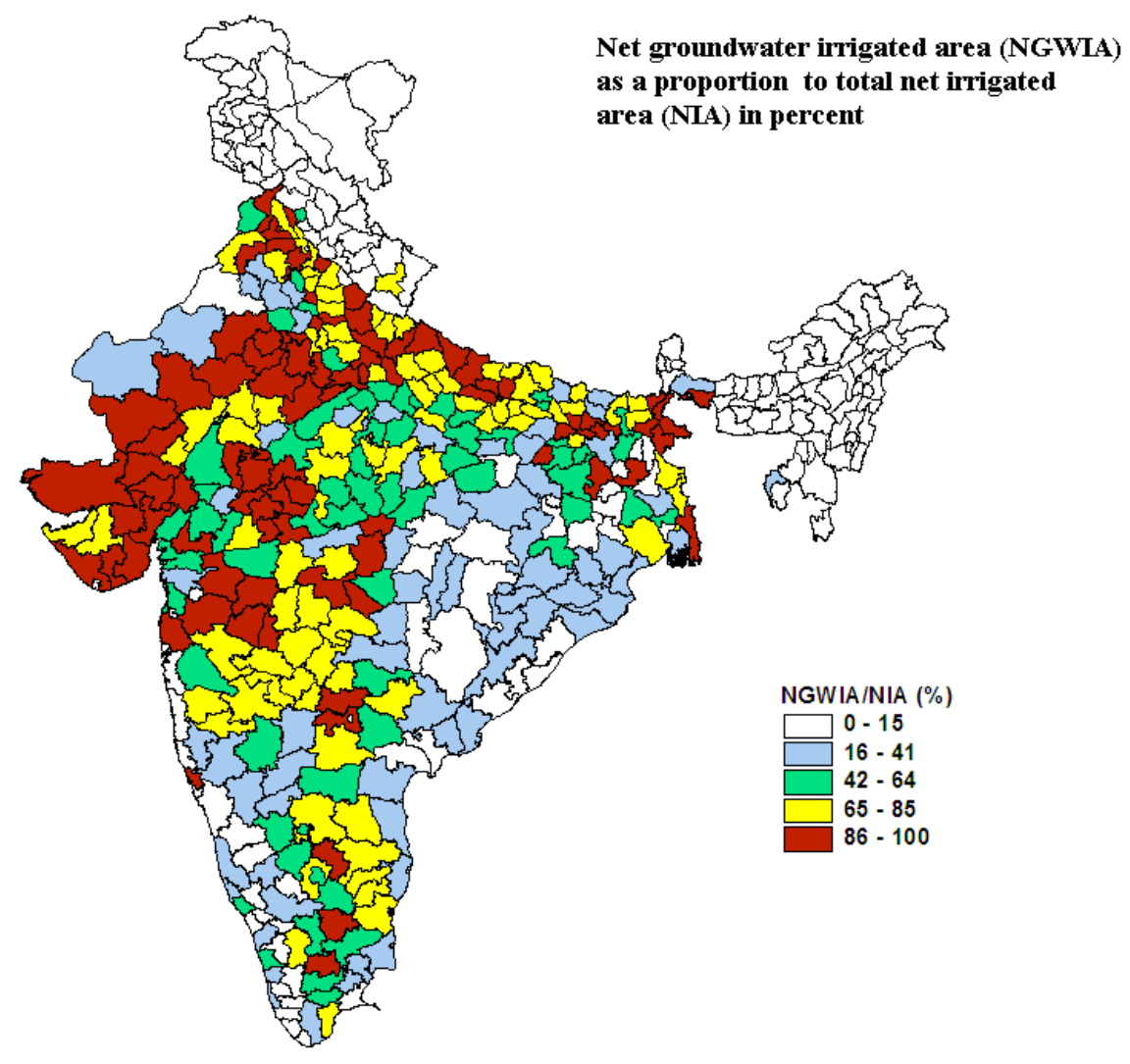




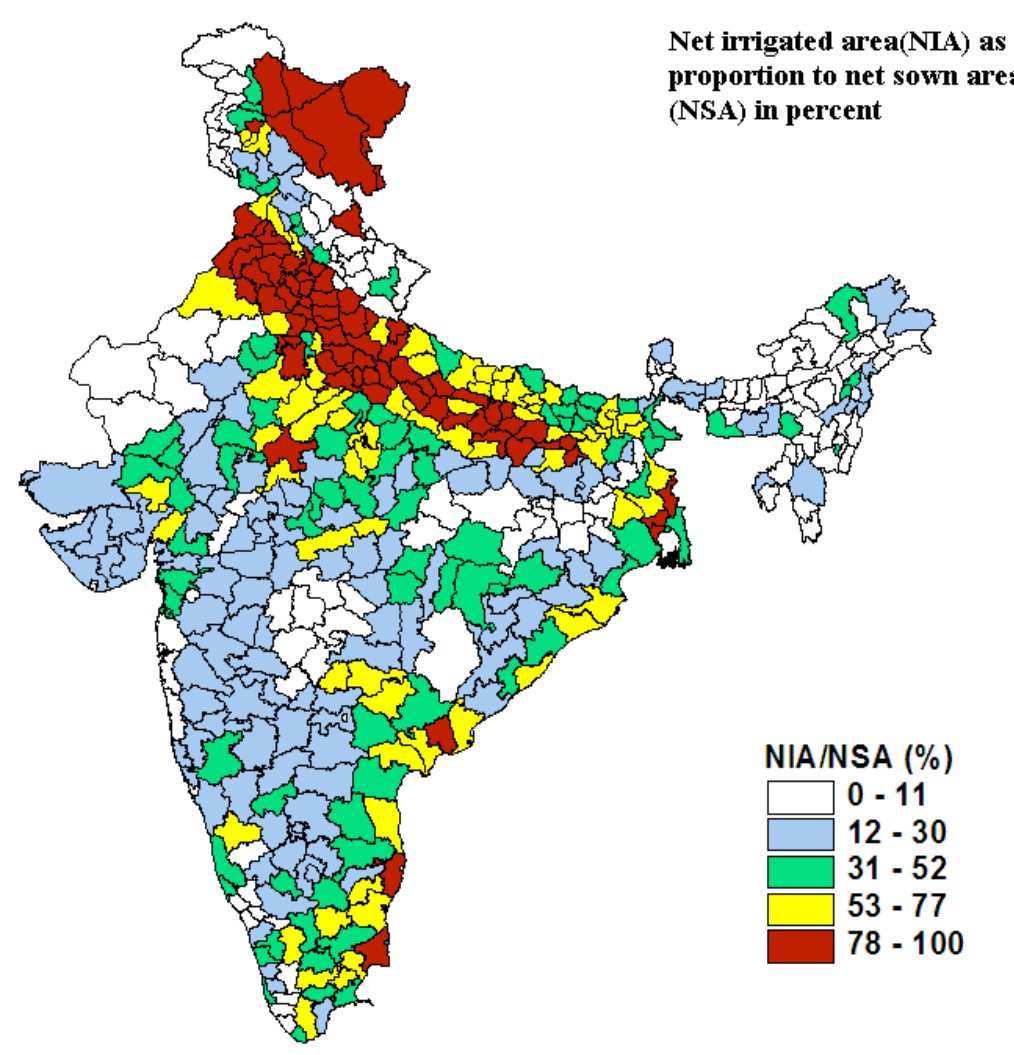




\section{Annex B}

\section{Computation of the source of gross irrigated area growth}

Suppose gross irrigated area (GIA) is a function of canals (canal), tanks(Tank) and groundwater (Totwell).

It can be expressed as GIA $=f($ canals, Tanks, Totwell $)$. Taking total change of the function , we get $\Delta G I A=\frac{\partial f}{\partial \text { canal }}[\Delta$ canal $]+\frac{\partial f}{\partial \text { Tank }}[\Delta$ Tank $]+\frac{\partial f}{\partial \text { Totwell }}[\Delta$ Totwell $]$

where $\frac{\partial f}{\partial i}$ is the marginal change of GIA due to change in $\mathrm{i}^{\text {th }}$ source of irrigation $(\mathrm{i}=$ canal, tank, Totwell), and $\Delta(i)$ is the total change in ith factor.

So the contribution of canals in the relative change of GIA from year 1990 to 2000 can be expressed as $\frac{\frac{\partial f}{\partial c a n a l} \Delta \text { canal }}{\Delta G I A}$ or $\frac{\frac{\partial f}{\partial \text { canal }}\left[\text { canal }_{2000}-\text { canal }_{1990}\right]}{\left[G_{2000}-G I A_{1990}\right]}$; where from Table 3 and equation 1 , we get $\frac{\partial f}{\partial \text { canal }}=1.42$

\section{End Notes:}

\footnotetext{
${ }^{\mathrm{i}}$ There are many crops like sugarcane, banana, coconut etc stands for more than three months in the field. In commuting the intensity it need some special consideration. Unlike the conventional measure of irrigation intensity, defined as the ratio of gross irrigated area (GIA) to net irrigated area (NIA), (GIA/NIA), we have computed irrigated land use intensity (ILUI) as $\frac{g i a+\sum_{j}^{n} n i a^{j}}{n i a}$ where $\mathrm{j}$ is the number of annual and perennial crops, which stands more the one cropping season in the field.

ii Separate data on conjunctive usage of Groundwater and surface irrigation is not available.

iii The NSA is about 142 million ha over this period. The NSA per person in the agriculture dependent population has decreased from 0.29 ha/person in 1990 to $0.26 \mathrm{ha} /$ person in 2000.

${ }^{\text {iv }}$ We have modified the usual definition of gross irrigated area to account for annual and perennial crops .
} 